ISSN 1392-3196 / e-ISSN 2335-8947

Zemdirbyste-Agriculture, vol. 105, No. 2 (2018), p. 171-176

DOI $10.13080 /$ z-a.2018.105.022

\title{
Efficient isolation of chloroplasts from in vitro shoots of Malus and Prunus
}

\author{
Šarūnė MORKŪNAITĖ-HAIMI, Jurgita VINSKIENĖ, Gražina STANIENĖ, Perttu HAIMI \\ Institute of Horticulture, Lithuanian Research Centre for Agriculture and Forestry \\ Kauno 30, Babtai, Kaunas distr., Lithuania \\ E-mail: s.morkunaite-haimi@1sdi.lt
}

\begin{abstract}
Investigation of cellular subfraction proteomes allows the study of specific changes induced by environmental changes, stress and other conditions. Chloroplasts participate in a huge number of complex biochemical processes in plant cells by retrograde signalling, as well as by sensing and responding to cellular dysfunction. Changes in environmental conditions in a controlled way are easily achieved in in vitro model systems. However, growing plants in vitro makes it difficult to obtain sufficient material for chloroplast isolation. Therefore, the chloroplast isolation method needs to be optimised for achieving sufficient yield from a small amount of sample. We used three species of Rosaceae family that are of high agricultural interest for breeding programs in Lithuania. The method used for chloroplast isolation from Arabidopsis thaliana was optimized for Malus domestica, M. platycarpa and Prunus avium. Homogenisation of $3 \mathrm{~g}$ of in vitro plant material in sorbitol-based isolation medium with a laboratory blender yielded a sufficient amount of chloroplasts for proteomic analysis. The purity of the fraction was highly increased by additional step of centrifugation at $200 \times \mathrm{g}$. The purity of chloroplasts was evaluated visually by microscopy, by immunoblotting with specific antibodies, as well as by using marker proteins and quantitative mass spectrometry. Although microscopy showed negligible amounts of cellular debris in all of the preparations, immunoblotting allowed detection of the presence of cytosolic marker in some of the preparations. Mass spectrometric analysis of marker proteins confirmed the presence of modest amount of non-chloroplast proteins. In conclusion, the presented method for chloroplast isolation for the Rosacea plants in vitro gives sufficient yield and purity for subcellular proteomic studies.
\end{abstract}

Key words: mass spectrometry, Percoll, protein abundance index, subcellular markers, Western blot.

\section{Introduction}

Chloroplasts are an essential organelle for plant productivity. Besides photosynthesis, chloroplasts are crucial for many other complex biochemical processes. These organelles synthesize fatty acids and lipids, most of the amino acids, vitamins, plant hormones as well as many other essential compounds. Chloroplasts are sensitive to the environmental changes and play a key role in plant cellular signalling (Ensminger et al., 2006; Stael et al., 2011; Crosatti et al., 2013). The importance of chloroplasts in adapting to environmental changes is related to both - sensing of the changes and triggering the response (Pfannschmidt, Yang, 2012; Miura, Furumoto, 2013).

A way to study the plant response to the environmental conditions is by measuring the changes in the proteins caused by environmental changes. However, the number of different proteins present in plants is larger than that of genes because of post-translational modifications, alternative splicing and other processes. To make matters worse, the concentration of different proteins varies by several degrees of magnitude. Thus, investigating the proteome of subcellular fractions is an effective technique for reducing the sample complexity, as well as giving additional insight into cellular processes such as protein sorting and import. Chloroplasts are of particular interest for plant biologists because of their complex biochemical pathways for essential metabolic functions (Baginsky, Gruissem, 2004).

Growing plants in controlled conditions in vitro helps to manipulate the environment and reproducibly, as well as follow the changes in plant response. However, working with in vitro plants leads to small amounts of plant sample, necessitating the optimization of the harvesting process. Protoplastation prior to chloroplast isolation is a time consuming and expensive method (Aronsson, Jarvis, 2002). There are methods for isolation of tissue specific chloroplasts; however, these procedures include genetic modification (Truernit, Hibberd, 2007). Isolating chloroplasts for further proteomic studies from small amounts of

Please use the following format when citing the article: 
sample material should give high yield and good quality. However, the conditions for the best yield and quality vary among species. Most of the studies are performed with model species like Arabidopsis thaliana.

Mass spectrometric quantification of marker protein ensembles was proposed by Andreyev et al. (2010) as a method for evaluating organelle purity. We applied this method for quality control of chloroplast isolation. Since the original method was developed with animal cells, we needed to extend it for plant cells, as well as to include chloroplast marker proteins. We compared the performance of the mass spectrometric method with immunoblotting.

Our goal was to achieve good quality and sufficient yield of chloroplasts from agriculturally important species of Malus and Prunus grown under in vitro conditions and to optimize the conditions for chloroplast isolation from orchard plants grown in vitro.

\section{Materials and methods}

Chloroplast isolation. The experiments were carried out at the Institute of Horticulture, Lithuanian Research Centre for Agriculture and Forestry in 20152016. We used three species of Rosaceae family: Malus domestica, M. platycarpa and Prunus avium. Plants were grown in vitro on modified MS (Murashige, Skoog, 1962) medium supplemented with $3.2 \mu \mathrm{M}$ benzylaminopurine, $3 \%$ sucrose and $0.8 \%$ plant agar. The shoots were grown at $22 \pm 3^{\circ} \mathrm{C}$ under fluorescent lamp illumination 50 $150 \mu \mathrm{mol} \mathrm{m}^{-2} \mathrm{~s}^{-1}$ intensity and $16 / 8 \mathrm{~h}$ photoperiod.

Due to small biomass of in vitro shoots, the leaves and stems were not separated. However, when possible, the amount of stems was minimized. Approximately $3 \mathrm{~g}$ of plant material was collected for each of chloroplast isolations. Thee repetitions of chloroplast isolation were done for each condition (isolation medium, homogenisation type, differential and Percoll centrifugations). We used two isolation mediums: a sorbitol based medium, as described by Kley et al. (2010), and a high salt medium, as described in Shi et al. (2012). Plant homogenization was done using a laboratory blender (Waring, USA), basic ultra-turrax polytron homogenizer Ika T 10 (IKA, Germany), or liquid nitrogen with mortar and pestle.

The plant material was blended in the medium containing 0.3 M sorbitol, $50 \mathrm{mM}$ 4-(2-hydroxyethyl)-1piperazineethanesulfonic acid (HEPES)/KOH ( $\mathrm{pH} 7.5)$, $5 \mathrm{mM}$ ethylenediaminetetraacetic acid (EDTA), $5 \mathrm{mM}$ ethyleneglycoltetraacetic acid (EGTA), $1 \mathrm{mM} \mathrm{MgCl}_{2}$, $10 \mathrm{mM} \mathrm{NaHCO}$, and freshly added $0.5 \mathrm{mM}$ dithiothreitol (DTT) using a small volume Waring laboratory blender at low speed twice for $5 \mathrm{sec}$. The homogenate was filtrated through double layer of nylon mesh and applied straight to $50 \%$ Percoll or centrifuged at $200 \times \mathrm{g}$ for $3 \mathrm{~min}$ and then applied to $50 \%$ Percoll. Subsequent centrifugation was performed at $2000 \times \mathrm{g}$ in a swing-out rotor for $10 \mathrm{~min}$. The green band was collected, re-suspended in the medium without DTT and centrifuged at $1000 \times \mathrm{g}$ for $5 \mathrm{~min}$. Obtained chloroplasts were used for further investigation.

High salt isolation medium composition was $1.25 \mathrm{M} \mathrm{NaCl}, 50 \mathrm{mM}$ Tris- $\mathrm{HCl}$ (pH 8.0), $5 \mathrm{mM}$
EDTA. In contrast to the original method (Shi et al., 2012), bovine serum albumin (BSA) was omitted and $\beta$-mercaptoethanol was replaced by DTT.

The yield of isolated chloroplasts was expressed on a unit chlorophyll basis ( $\mathrm{mg}$ of chlorophyll) measured at $652 \mathrm{~nm}$ by Implen NanoPhotomer (Implen, Germany). All solutions, tubes, glassware and equipment were precooled before experiments and kept at $0-4^{\circ} \mathrm{C}$ during all experiments. Plant removal from the in vitro medium and the basal part dissection was performed in room temperature.

The purity of chloroplast fraction was estimated by counting presence of full cells in $0.02 \mathrm{~mm}^{2}$ area of microscopy slide with chloroplast fraction using microscope Nikon Eclipse 80i (Japan).

Western blot analysis. Total proteins were extracted by phenol method (Isaacson et al., 2006) and solubilised in $2 \%$ sodium dodecyl sulphate (SDS). Concentration was determined using Roti-Quant universal reagent (Carl Roth). $5 \mu \mathrm{g}$ of proteins with $4 \times$ Laemmli sample buffer (BioRad) were analysed on $5 / 12 \%$ SDS polyacrylamide gel electrophoresis and electroblotted onto Hybond-P polyvinylidene fluoride membrane (GE Healthcare, UK).

To test the purity of Malus chloroplast fraction, membranes were probed with rabbit anti-UDP-glucose pyrophosphorylase (UGPase, dilution 1:2500; a marker for cytosolic contamination), isocitrate dehydrogenase (IDH, dilution 1:2500; a marker for mitochondrial contamination) antibodies. Antibodies were detected by incubation with goat anti-rabbit Ig horseradish peroxidase-linked polyclonal antibody (dilution 1:5000) using the enhanced chemiluminescence (ECL) system (BioRad) and Clarity Western ECL substrate (BioRad). Films were scanned using scanner Typhoon FLA900 and analysed by program ImageQuant TL (GE Healthcare, UK).

Mass spectrometry (MS). The chloroplast proteins were pre-fractioned using SDS-PAGE. The lane with chloroplast proteins was cut to ten equal sized pieces, and the proteins were digested using trypsin (Sevchenko et al., 2007). In-gel digested tryptic peptides were concentrated and washed on a trap column Acclaim PepMap100 C18 (Dionex, USA) and separated by $75 \mu \mathrm{m} \times 15 \mathrm{~cm}$ Acclaim PepMap RSLC C18 (Dionex), with a 60 minute gradient from $5 \%$ to $40 \% \mathrm{~B}(\mathrm{~A}-0.1 \%$ formic acid (FA), B - 0.1\% FA in acetonitrile (ACN) using Ultimate 3000 RSLCnano LC system (Dionex). MS and collision induced dissociation (CID) MS/MS spectra were measured with Bruker maXis $4 \mathrm{G}$ equipped with CaptiveSpray nano-electrospray source (Bruker Daltonics $\mathrm{GmbH}$, Germany). The mass spectra were internally calibrated using hexakis lock mass standard. Proteins were identified by Mascot (Matrix Science) search with $10 \mathrm{ppm}$ mass tolerance against either Malus $\times$ domestica consensus gene model proteins (Velasco et al., 2010). Data was checked for contaminating peptides by performing a Mascot search against the database SwissProt (Boutet et al., 2016). The peptide matches were visualized and validated using the software Proteinscape (Bruker Daltonics). The exponentially modified protein abundance index (emPAI) was employed for quantitation of the proteins. This index is calculated from the number 
of observed peptides, normalized by the number of observable peptides per protein, and has been previously shown to be proportional to the protein concentration in a protein mixture (Ishihama et al., 2005).

Bioinformatics. The functional annotation of gene model proteins was done using a Blast search against the non-redundant sequence database at NCBI (Pruitt et al., 2005) and by Argot (Falda et al., 2012).
The criteria for marker proteins used for purity analysis were the following: (1) they had a high confidence annotation in the database UniProt (UniProt Consortium, 2015), (2) previously described in literature (Andreyev et al., 2010; Ferro et al., 2010) and (3) availability of antibodies (Table 1). Proteins that are exclusively found in a specific organelle were prioritized.

Table 1. Organelle marker proteins quantified using mass spectrometry

\begin{tabular}{|c|c|c|c|c|}
\hline Location & Malus ID & emPAI & UniProt ID & Description \\
\hline Chloroplast & MDP0000294406 & 2.06 & O81439 & Plastoglobulin 35 \\
\hline Chloroplast & MDP0000198078 & 8.12 & P10933 & Ferredoxin-NADP reductase \\
\hline Chloroplast & MDP0000602932 & 0.66 & Q9M591 & MPE-cyclase \\
\hline Chloroplast & MDP0000708928 & 1.61 & O82425 & Chlorophyll $\mathrm{a}-\mathrm{b}$ binding protein \\
\hline Chloroplast & MDP0000149416 & 0.48 & D7TWA1 & Ferredoxin-plastoquinone reductase 2 \\
\hline Chloroplast & MDP0000597996 & 2.22 & $\mathrm{~B} 2 \mathrm{MZZ1}$ & Rubisco large subunit \\
\hline Chloroplast & MDP0000706975 & 3.7 & $\mathrm{O} 24500$ & Glycolate oxidase \\
\hline Chloroplast & MDP0000624350 & 2.98 & A5AEB4 & Photosystem I reaction centre subunit II \\
\hline Chloroplast & MDP0000464827 & 1.75 & E3W0J3 & Photosystem I P700 chlorophyll a apoprotein A1 \\
\hline Chloroplast & MDP0000233921 & 1.61 & B9S1T5 & $\mathrm{O} 2$ evolving complex $33 \mathrm{kD}$ family protein \\
\hline Mitochondria & MDP0000295277 & 0.06 & B9RZW7 & Dihydrolipoyl dehydrogenase \\
\hline Mitochondria & MDP0000874020 & 0.0 & Q39219 & Ubiquinol oxidase $1 \mathrm{a}$ \\
\hline Mitochondria & MDP0000216734 & 0.28 & Q9T070 & Cytochrome c oxidase subunit $6 \mathrm{a}$ \\
\hline Mitochondria & MDP0000309512 & 0.12 & Q945K7 & Isocitrate dehydrogenase \\
\hline Mitochondria & MDP0000332597 & 0.0 & Q9SZJ5 & Serine hydroxymethyltransferase 1 \\
\hline ER & MDP0000327191 & 0.4 & P33157 & Beta-1,3-endoglucanase (PR-2) \\
\hline ER & MDP0000322220 & 0.5 & Q9LKR3 & Heat shock protein $70-11$ \\
\hline ER & MDP0000122791 & 0.0 & Q9LM02 & Sterol methytransferase \\
\hline Peroxisome & MDP0000279170 & 0.0 & Q8VZD4 & Glyoxysomal processing protease \\
\hline Peroxisome & MDP0000132452 & 1.73 & F6I0K4 & Catalase \\
\hline Peroxisome & MDP0000172852 & 0.78 & Q9C9W5 & Glycerate dehydrogenase HPR \\
\hline Peroxisome & MDP0000145531 & 0.0 & Q9FXT6 & Peroxisomal membrane protein PEX14 \\
\hline Nucleus & MDP0000624481 & 0.0 & Q9FF75 & Nucleoskeleton linkage protein \\
\hline Nucleus & MDP0000464636 & 0.0 & Q8RWK8 & Coilin \\
\hline Nucleus & MDP0000024484 & 1.25 & Q2XPW1 & Histone $\mathrm{H} 2$ \\
\hline Cytosol & MDP0000251810 & 0.0 & Q9MA79 & Fructose-1,6-bisphosphatase \\
\hline Cytosol & MDP0000171559 & 0.23 & B7FH28 & Large ribosomal subunit \\
\hline Cytosol & MDP0000306580 & 0.0 & Q94BT0 & Sucrose-phosphate synthase 1 \\
\hline Cytosol & MDP0000323036 & 0.0 & Q9M9P3 & UDP-glucose pyrophosphorylase 2 \\
\hline Cell wall & MDP0000209964 & 0.0 & P93046 & ХТН-31 \\
\hline Cell wall & MDP0000605874 & 0.21 & B9RG92 & Aspartic-type endopeptidase \\
\hline Cell wall & MDP0000470441 & 0.0 & Q9SWW6 & Cellulose synthase A subunit \\
\hline Cell wall & MDP0000740981 & 0.0 & K4ELD8 & Endoglucanase \\
\hline
\end{tabular}

ER - endoplasmic reticulum, emPAI - protein abundance index

\section{Results and discussion}

Although chloroplast isolation can be preceded by the use of the cell wall-degrading enzymes (cellulase and pectinase) for protoplastation (Aronsson, Jarvis, 2002), this additional step adds considerable cost and complexity to the method. On the other hand, mechanical rupturing of cell wall and membrane, leading to the release of chloroplasts to the isolation medium is relatively easy and inexpensive. However, this step is very important for the yield and quality - too soft homogenization decreases the yield, whereas too intensive homogenization would lead to rupture of not only the cell membrane, but also the chloroplast envelope.

Effect of homogenization. Plant tissue grinding with mortar and pestle is a very common method for disruption of biological samples. Homogenization with polytron was described in Aronsson and Jarvis (2002) work as leading to the best results, whereas Kley et al. (2010) preferred a mini blender. We compared these three methods for isolating chloroplast form Malus species. Table 2 summarizes the results. In our experience, homogenization with liquid nitrogen did not lead to high yields and was slightly more time consuming, whereas polytron homogenization yielded the least amount of chloroplasts. Laboratory blender was chosen for further experiments since yield was highest and it was the fastest of the three methods.

In vitro plants for chloroplast isolation should be at least 6 weeks old to allow time for the leaves to reach sufficient mass compared to the stem. The exception is Prunus avium, which forms short shoots with relatively large leaves. High proportion of mass from the leaves in this species leads to higher yield of chloroplast fraction. 
Table 2. Chlorophyll concentration in chloroplast fractions using different homogenization methods

\begin{tabular}{lc}
\hline Homogenization method & $\begin{array}{c}\text { Chlorophyll concentration } \\
\mathrm{mg} 3 \mathrm{~g}^{-1} \\
\text { fresh plant material }\end{array}$ \\
\hline Liquid nitrogen & $0.105 \pm 0.061$ \\
Polytron homogenizer & $0.085 \pm 0.059$ \\
Waring laboratory blender & $0.125 \pm 0.012$ \\
\hline
\end{tabular}

Effect of the isolation buffer. There are many reports of successful isolation of intact chloroplasts with varying composition of the isolation medium (Kley et al., 2010; Grabsztunowicz, Jackowski 2012; Shi et al., 2012; Vieira et al., 2014). This suggests that the choice of buffer, osmoticum, salts, reducing agents and other additives is not critical. The addition of bovine serum albumin (BSA) to the isolation buffer might reduce the damage caused by proteolytic enzymes, but it would not be compatible with proteomic analysis due to the significant interference with the downstream measurements. Isolation medium with sorbitol and 4-(2-hydroxyethyl)-1-piperazineethanesulfonic acid (HEPES) is very commonly used. However, some authors found that a high salt method gives better yield of chloroplast compared to a sucrose gradient method (Shi etal., 2012; Vieira etal., 2014).
Presumably, using the high salt method for chloroplast isolation has the advantage that hypertonic conditions will prevent chloroplasts from rupturing during isolation. In our experiments, the high salt method did not have significant effect either on yield or on purity. Therefore, the sorbitol based medium, which is close to isotonic was used in further experiments.

Purity of the chloroplast fraction. Chloroplast fraction was investigated by microscopy for evaluating the purity and integrity of the chloroplasts. Unbroken or partially broken cells were present in the chloroplast fraction if the homogenate was applied on Percoll directly. The presence of cell debris was significantly reduced if there was an extra centrifugation step at $200 \times \mathrm{g}$ before applying the filtrate to the Percoll. The pellet was investigated by microscopy and in addition to some unbroken cells; there was a large amount of chloroplasts that sedimented at low speed. This fraction was considered as the cellular fraction and investigated by immunoblotting. Extra centrifugation at low speed increased the purity, but also highly reduced the amount of chlorophyll (Table 3). This amount, however, is still comparable to that obtained in previous studies (Aronsson, Jarvis, 2002; Ferro et al., 2010) and corresponds to 200-300 $\mu \mathrm{g}$ of protein, which is sufficient for proteomic analysis (Kley et al., 2010).

Table 3. The purity of chloroplast fractions estimated by microscopy and the concentration of chlorophyll

\begin{tabular}{|c|c|c|c|}
\hline \multicolumn{2}{|c|}{ Full cells present in microscope slide } & \multicolumn{2}{|c|}{ Chlorophyll concentration mg $3 \mathrm{~g}^{-1}$ fresh material } \\
\hline Percoll & differential and Percoll & Percoll & differential and Percoll \\
\hline $4.8 \pm 5.60$ & $0.3 \pm 0.46$ & $0.17 \pm 0.264$ & $0.08 \pm 0.043$ \\
\hline
\end{tabular}

Immunoblotting with cytosolic marker protein (anti-UGPase / UDP-glucose phosphorylase) produced a strong band in the positive control (total protein extract) and a weak band in the cellular fraction, as well as in one of the chloroplast fractions). Cellular or mitochondrial contaminations are common in chloroplast fraction and cytosolic marker enzyme activity was reported to account for $2-6 \%$ of the activity in the total leaf (Kley et al., 2010; Grabsztunowicz, Jackowski, 2012). However, most of our chloroplast preparations did not have a detectable cytosolic marker band. The mitochondrial marker (antiIDH / isocitrate dehydrogenase) was only detectable in the positive control (Fig. 1).

Mass spectrometric quantification of marker proteins revealed varying amounts of organelle-specific proteins (Table 1). In general, the chloroplast marker

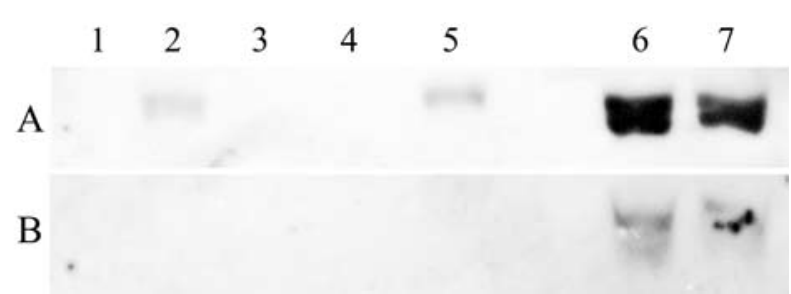

Note. The primary antibody used was cytosolic marker antiUGPase / UDP-glucose phosphorylase (A) and mitochondrial marker anti-IDH / isocitrate dehydrogenase (B).

Figure 1. Immunoblot of purified chloroplasts (1, 2, 3, 4 ), cell fraction (pellet after $200 \times \mathrm{g})(5)$ and total (nonfractioned) phenol-extracted proteins $(6,7)$ proteins had the highest protein abundance index (emPAI) value that is proportional to protein content in a protein mixture, although there were some exceptions such as the peroxisomal catalase and nuclear histone $\mathrm{H} 2$ protein, which had high emPAI values (1.73 and 1.25 , respectively). The average emPAI values for each organelle were calculated to estimate the contribution of the proteins originating from each organelle (Fig. 2),

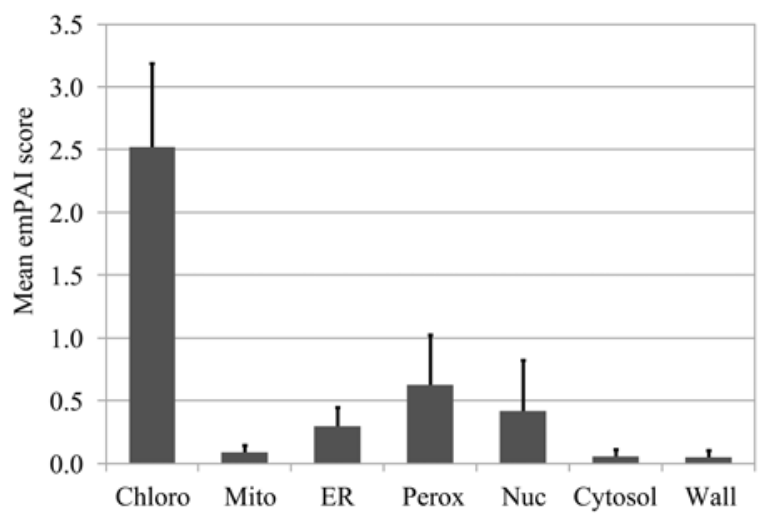

Note. Compartments labelled: Chloro - chloroplasts, Mito - mitochondria, ER - endoplasmic reticulum, Perox peroxisomes, Nuc - nucleus, Cytosol - cytosole, Wall - cell wall; marker amount expressed as protein abundance index error bars indicate the $95 \%$ confidence interval of the mean.

Figure 2. Mean marker protein amount per subcellular location 
corresponding to $62,2,7,15,10,1$ and 1 percentage points for chloroplast, mitochondrial, endoplasmic reticulum, peroxisomal, nuclear, cytosolic and cell wall proteins, respectively. Thus, the main contaminants appear to originate from peroxisomes and nuclei.

\section{Conclusions}

1. We present an efficient chloroplast isolation method for small in vitro samples for Malus and Prunus species. The method is suitable and provides sufficient yield for proteomic studies. The purity of the chloroplasts was evaluated by immunoblotting as well as by quantitative mass spectrometry of marker proteins.

2. In our experience, the sensitivity of detection is better for the marker protein isocitrate dehydrogenase in mass spectrometry. However, the marker enzyme UDP-glucose pyrophosphorylase could not be detected with either method. This likely reflects the low amount of cytosolic contamination in our preparations.

3. The use of quantitative mass spectrometry for the assay of marker enzymes appears to be a sensitive and reliable method for the quality control of subcellular fractions.

\section{Acknowledgements}

We thank Adelè Lipavičiūtè and Laura Liutkevičiūte for technical assistance in chloroplast preparation. The research was funded by the Research Council of Lithuania, grant No. MIP-061/2015.

Received 28082017

Accepted 11032018

\section{References}

1. Andreyev A. Y., Shen Z., Guan Z., Ryan A., Fahy E., Subramaniam S., Raetz C., Briggs S., Dennis E. A. 2010. Application of proteomic marker ensembles to subcellular organelle identification. Molecular and Cellular Proteomics, 9 (2): 388-402.

https://doi.org/10.1074/mcp.M900432-MCP200

2. Aronsson H., Jarvis P. 2002. A simple method for isolating import-competent Arabidopsis chloroplasts. FEBS letters, 529 (2-3): 215-220.

https://doi.org/10.1016/S0014-5793(02)03342-2

3. Baginsky S., Gruissem W. 2004. Chloroplast proteomics: potentials and challenges. Journal of Experimental Botany, 55: $1213-1220$.

https://doi.org/10.1093/jxb/erh104

4. Boutet E., Lieberherr D., Tognolli M., Schneider M., Bansal P., Bridge A. J., Poux S., Bougueleret L., Xenarios I. 2016. UniProtKB/Swiss-Prot, the manually annotated section of the UniProt KnowledgeBase: how to use the entry view. Methods in Molecular Biology, 1374: 23-54. https://doi.org/10.1007/978-1-4939-3167-5_2

5. Crosatti C., Rizza F., Badeck F. W., Mazzucotelli E., Cattivelli L. 2013. Harden the chloroplast to protect the plant. Physiologia Plantarum, 147: 55-63. https://doi.org/10.1111/j.1399-3054.2012.01689.x

6. Ensminger I., Busch F., Huner N. P. A. 2006. Photostasis and cold acclimation: sensing low temperature through photosynthesis. Physiologia Plantarum, 126: 28-44. https://doi.org/10.1111/j.1399-3054.2006.00627.x
7. Falda M., Toppo S., Pescarolo A., Lavezzo E., Di Camillo B., Facchinetti A., Cilia E., Velasco R., Fontana P. 2012. Argot2: a large scale function prediction tool relying on semantic similarity of weighted Gene Ontology terms. BMC Bioinformatics, 13 (4): S14. https://doi.org/10.1186/1471-2105-13-S4-S14

8. Ferro M., Brugière S., Salvi D., Seigneurin-Berny D., Court M., Moyet L., Ramus C., Miras S., Mellal M., Le Gall S., Kieffer-Jaquinod S., Bruley C., Garin J, Joyard J., Masselon C., Rolland N. 2010. AT_CHLORO, a comprehensive chloroplast proteome database with subplastidial localization and curated information on envelope proteins. Molecular and Cellular Proteomics, 9: 1063-108.

https://doi.org/10.1074/mcp.M900325-MCP200

9. Grabsztunowicz M., Jackowski G. 2012. Isolation of intact and pure chloroplasts from leaves of Arabidopsis thaliana plants acclimated to low irradiance for studies on Rubisco regulation. Acta Societatis Botanicorum Poloniae, 82: 91-95.

https://doi.org/10.5586/asbp.2012.043

10. Isaacson T., Damasceno C., Saravanan R., He Y., Catalá C., Saladie M., Rose J. 2006. Sample extraction techniques for enhanced proteomic analysis of plant tissues. Nature Protocols, 1: 769 .

https://doi.org/10.1038/nprot.2006.102

11. Ishihama Y., Oda Y., Tabata T., Sato T., Nagasu T., Rappsilber J., Mann M. 2005. Exponentially modified protein abundance index (emPAI) for estimation of absolute protein amount in proteomics by the number of sequenced peptides per protein. Molecular and Cellular Proteomics, 4: 1265-1272.

https://doi.org/10.1074/mcp.M500061-MCP200

12. Kley J., Heil M., Muck A., Svatos A., Boland W. 2010. Isolating intact chloroplasts from small Arabidopsis samples for proteomic studies. Analytical Biochemistry, 398 (2): 198-202. https://doi.org/10.1016/j.ab.2009.11.016

13. Miura K., Furumoto T. 2013. Cold signaling and cold response in plants. International Journal of Molecular Sciences, 14 (3): 5312-5337. https://doi.org/10.3390/ijms14035312

14. Murashige T., Skoog F. 1962. A revised medium for rapid growth and bioassays with tobacco tissue cultures. Physiologia Plantarum, 15: 473-497. https://doi.org/10.1111/j.1399-3054.1962.tb08052.x

15. Pfannschmidt T., Yang C. 2012. The hidden function of photosynthesis: a sensing system for environmental conditions that regulates plant acclimation responses. Protoplasma, 249 (suppl. 2): S125-S136. https://doi.org/10.1007/s00709-012-0398-2

16. Pruitt K. D., Tatusova T., Maglott D. R. 2005. NCBI reference sequence (RefSeq): a curated non-redundant sequence database of genomes, transcripts and proteins. Nucleic Acids Research, 33 (database iss.): D501-D504.

17. Sevchenko A., Tomas H., Havlis J., Olsen J., Mann M. 2007. In-gel digestion for mass spectrometric characterization of proteins and proteomes. Nature Protocols, 1: 2856. https://doi.org/10.1038/nprot.2006.468

18. Shi C., Hu N., Huang H., Gao J., Zhao Y. J., Gao L. Z. 2012. An improved chloroplast DNA extraction procedure for whole plastid genome sequencing. PLoS ONE, 7: e31468. https://doi.org/10.1371/journal.pone.0031468

19. Stael S., Wurzinger B., Mair A., Mehlmer N., Vothknecht U., Teige M. 2011. Plant organellar calcium signalling: an emerging field. Journal of Experimental Botany, 63: 1525-1542. https://doi.org/10.1093/jxb/err394 
20. UniProt Consortium. 2015. UniProt: a hub for protein information. Nucleic Acids Research, 43 (database iss.): D204-D212.

21. Truernit E., Hibberd J. M. 2007. Immunogenic tagging of chloroplasts allows their isolation from defined cell types. The Plant Journal, 50: 926-932. https://doi.org/10.1111/j.1365-313X.2007.03113.x

22. Velasco R., Zharkikh A., Affourtit J. et al. 2010. The genome of the domesticated apple (Malus $\times$ domestica Borkh.). Nature Genetics, 42 (10): 833-839.

https://doi.org/10.1038/ng.654
23. Vieira L. do N., Faoro H., Fraga H. P., Rogalski M., de Souza E. M., de Oliveira Pedrosa F., Nodari R. O., Guerra M.P. 2014. An improved protocol for intact chloroplasts and cpDNA isolation in conifers. PLoS ONE, 9 (1): e84792.

https://doi.org/10.1371/journal.pone.0084792

ISSN 1392-3196 / e-ISSN 2335-8947

Zemdirbyste-Agriculture, vol. 105, No. 2 (2018), p. 171-176

DOI $10.13080 /$ z-a.2018.105.022

\title{
Efektyvus chloroplastų išskyrimas iš Malus ir Prunus mikroūgliụ
}

\author{
Š. Morkūnaitè-Haimi, J. Vinskienè, G. Stanienè, P. Haimi \\ Lietuvos agrarinių ir miškų mokslų centro Sodininkystės ir daržininkystès institutas
}

\begin{abstract}
Santrauka
Subląsteliniu frakcijų proteomikos tyrimai leidžia nustatyti specifinius aplinkos kitimo, streso ar kitų sąlygų nulemtus pokyčius. Chloroplastai dalyvauja daugelyje sudètingų biocheminių procesų, sąlygojančių ląstelès grįžtamojo signalo perdavimą. Jausdami ląstelès funkcijų sutrikimus chloroplastai atitinkamai i juos reaguoja. Kintamas kontroliuojamas sąlygas lengviausia sukurti in vitro sistemoje. Tačiau sodo augalus auginant in vitro yra sudètinga išauginti didelị kiekị žalios masès, reikalingos išskirti chloroplastams. Todell chloroplastų išskyrimo metodą reikia optimizuoti taip, kad išeiga būtu pakankama ir iš nedidelio kiekio medžiagos. Tyrimo metu naudotos trys Rosaceae šeimos rūšys, turinčios svarią agronominę vertę Lietuvos sodo augalų selekcijos programoje. Arabidopsis thaliana chloroplastams skirti tinkantis metodas buvo optimizuotas Malus domestica, M. platycarpa ir Prunus avium rūšims. Proteomikos tyrimams pakankama chloroplastų išeiga buvo gauta homogenizuojant $3 \mathrm{~g}$ in vitro augalų laboratoriniu smulkintuvu ir naudojant izoliavimo terpę sorbitolio pagrindu. Frakcijos grynumas reikšmingai padidèjo taikant papildomą lèto $(200 \times \mathrm{g})$ centrifugavimo žingsnį. Chloroplastų grynumas vertintas mikroskopu vizualiai, imunopernaša su specifiniais antikūnais ir kiekybine masių spektrometrija - pagal baltymus žymeklius. Nors mikroskopavimo metu visose chloroplastų frakcijų pavyzdžiuose nustatyti nereikšmingi kiekiai ląsteliụ priemaišų, imunopernašos metodu kai kuriuose pavyzdžiuose nustatyti ir citozoliniai žymekliai. Masių spektrometrijos analizė patvirtino nedidelius kiekius ne chloroplastams būdingų baltymų.
\end{abstract}

Reikšminiai žodžiai: baltymo gausumo indeksas, imunobloto metodas, masių spektrometrija, Percoll, subląsteliniai žymekliai. 